Robinson, Stephen (2014) 'To think, act, vote, and speak for ourselves': Black Democrats and black 'agency' in the American South after Reconstruction. Journal of Social History, 48 (2). pp. 363-382.

Downloaded from: http://ray.yorksj.ac.uk/id/eprint/1691/

The version presented here may differ from the published version or version of record. If you intend to cite from the work you are advised to consult the publisher's version: http://jsh.oxfordjournals.org/content/48/2/363

Research at York St John (RaY) is an institutional repository. It supports the principles of open access by making the research outputs of the University available in digital form. Copyright of the items stored in RaY reside with the authors and/or other copyright owners. Users may access full text items free of charge, and may download a copy for private study or non-commercial research. For further reuse terms, see licence terms governing individual outputs. Institutional Repository Policy Statement

\title{
RaY
}

Research at the University of York St John

For more information please contact RaY at ray@yorksj.ac.uk 


\section{"To think, act, vote, and speak for ourselves": Black Democrats and black "agency" in the American South after Reconstruction}

In late September 1885, a black convention was held in the Virginian town of Lynchburg. It was an election year in the state: a gubernatorial campaign that pitted the Republican candidate, John S. Wise, against Democrat Fitzhugh Lee, the nephew of Confederate general, Robert E. Lee. Both candidates needed the black vote, a fact that the African American conventioneers knew all to well. In their address, the delegates emphasised their gratitude towards the Republican Party for their role in abolishing slavery through the Thirteenth Amendment in 1865, and for their support of the Fourteenth and Fifteenth Amendments (which for the first time protected the citizenship rights of all Americans). Yet times had moved on, they argued; now was the time for African Americans, as free-people, "to think, act, vote, and speak for ourselves”. This had become apparent, the address stated, since the Republicans had "practically abandoned us". The sense now was that black southerners had to work with white southerners in this post-Reconstruction world and embrace their version of the immediate past. Rather than considering Reconstruction to be a worthy effort in creating a more equal society, the conventioneers, using the language of white southerners, instead referred to the post-war period as "the dark days of Reconstruction”. ${ }^{\mathrm{i}}$

The Lynchburg convention is significant because it revealed how some black southerners after Reconstruction wanted to break with the past and bring to an end their support for the Republican Party. Their feeling of abandonment alluded to the Republicans’ increasing lack of interest toward the former slaves, which had been made evident by the federal withdrawal from the South over the course of the 1870s. This had resulted in the restoration of southern "home rule" and the return to power of 
the Democrats. In addition, the decision of the predominantly Republican Supreme Court's decision two years previously, which had declared the 1875 Civil Rights Act as unconstitutional, reflected the growing white counter-reaction to Reconstruction. This decision was met with widespread opposition from African Americans, who knew all-to-well how it significantly undermined the effectiveness of the Fourteenth Amendment in upholding civil rights in the South.

The convention's address was an unambiguous statement in support of independent voting, for by the mid-1880s, any discussion of alternatives to the Republican Party was situated within a discourse of "independent voting”. In practice, this meant embracing the Democratic option, yet the term “independent” was important because it implied (perhaps naively in the context of the American South) that African Americans could be agents of their own political destiny in the South. As the Lynchburg convention reveals, there were some African Americans who wished to end their "unqualified support” for the Republican Party and at least consider working with white (Democratic) southerners. ${ }^{\text {ii }}$

This essay will offer some preliminary remarks regarding African Americans who supported the Democrats. I argue that a study of black Democrats after Reconstruction forces us to reconsider what we mean by African American "agency" in the post-bellum South. ${ }^{\text {iii }}$ We need to know much more about black conservative men who chose to support the Democrats, and situate any analysis in terms of the broader issues of race, class, gender and region. Local concerns determined the level of support, and whether support for the Democrats would come as a political bargain (usually in the form of a "fusion" ticket) or from direct political affiliation (in some cases with the promise of patronage). ${ }^{\text {iv }}$ The Lynchburg convention came at a highwater point for black "independent” voting in the Old Dominion, and in the South 
more generally. As this essay will reveal, black support for the Democrats would always be limited: both from a lack of white Democratic commitment, and as a result of open hostility from black Republicans.

It is understandable that historians have generally avoided studying black Democrats, given the fact that their numbers are hard to quantify. Those of the Dunning “school” of the early twentieth century, such as Walter L. Fleming's 1905 work, Civil War and Reconstruction in Alabama, praised such individuals for their heroism in the face of black Republican opposition. A more balanced account emerged in the mid-1950s with an article by the noted historian of black America, August Meier. Yet Meier's article, along with Lawrence Grossman's 1976 work, The Democratic Party and the Negro, predominantly focused on the northern wing of the party, whereas Randall Wood's article on C.H.J. Taylor, a prominent black attorney, concentrates on black independents in Kansas and at the national level. By and large, historians from the 1960s onward have played down southern black support for the Democrats - discounting the notion of blacks voluntarily being involved with groups like the Red Shirts in South Carolina. Joel Williamson's After Slavery: The Negro in South Carolina during Reconstruction is a case in point here, a work published in 1965 that, understandably for the time, wanted to counter the racist underpinning of the Dunning-era scholarship. ${ }^{\mathrm{v}}$

There are signs, however, that the debate has shifted a little, taking into account the local context. Edmund Drago's Hurrah for Hampton!, for example, focuses on the black Red Shirts: African Americans in South Carolina who supported the Democratic candidate for governor, Wade Hampton, during the 1876 state election. Drago does not really place these black Democrats within the 
broader context of Reconstruction-era politics, however, nor does he analyse in any detailed way the motivation of black leaders. Likewise, John Giggie's work on black political activity in post-Reconstruction Arkansas, while the most detailed study to date on black Democrats, has less to say on what motivated African Americans to support the Democrats in the first place. Giggie's analysis is set within the context of the black church, one that focuses on the close relationship between African Americans' religious and political life. His analysis concentrates on the 1888 state election, specifically on how the political activism of black church members, especially of black women, was central to the state's broader electoral politics. ${ }^{\text {vi }}$

What follows, therefore, is an exploration of black Democracy that takes the agency of the principal actors into account. It would be an error to simply assume that all black Democrats were duped into supporting the Democracy. Bribery and coercion were certainly present, and accounted for a large number of supposedly Democratic votes cast by African Americans, but this is to discount human agency in all its guises. As Walter Johnson notes on slavery, resistance cannot solely define agency; collaboration also has to be considered part of agency. This broader notion of human agency can be extended forward to Reconstruction and beyond. Like any politician, many of these men were opportunists, sensing which way the wind was blowing and then following it. In the years after Reconstruction, political deals with Southern whites were deemed by some black leaders as necessary if they were to retain any kind of influence. For others, as in the case of the Red Shirts, associating with the Democrats gave them status or the chance of patronage. ${ }^{\text {vii }}$ 
Determining why some black men chose to support the party that had defended slavery, that was not the party of Lincoln, is certainly a challenge. For one thing, the dividing line between free will and coercion is never clear-cut. The level of support is also hard to quantify, for the number of African Americans who voted for the Democrats were invariably inflated or deflated depending on where the figures are found. And that is without getting on to the subject of electoral fraud.

Yet there can be no denying the fact that the vast majority of African Americans who voted Democrat in the late nineteenth century did so as a result of intimidation. This was the image portrayed in the national press, and is supported by an abundance of evidence. ${ }^{\text {viii }}$ Those who chose to support the Democrats rather than being forced to (and the difference between these was well-known), carried the risk of social ostracism at best, physical violence at worst. ${ }^{\text {ix }}$

The majority of black Democrats in this period were from the black elite: men who were usually freeborn, of some social standing, and who were businessmen or clergymen. Many of these men had built up an economic base, which they wanted to preserve at all costs. They were therefore more conservative in their outlook than those formerly enslaved, who wanted radical land reform; their own "forty acres and a mule". Class divisions therefore had “political implications.” African American historian and sociologist W.E.B. Du Bois identified three types of black leader: those who were petty bourgeois, setting their sights on wealth creation; those who were educated and serving the broader nation "without regard to mere race lines"; and those whom he labelled “idealists" who advocated black self-determination, so that black Americans would be "on a par with the whites."x 
While these groups may have had some degree of overlap, it can be said that most black Democrats fell into the first category identified by Du Bois. Freeborn William B Scott of Tennessee is perhaps representative of this group. He had been a newspaper editor since 1865 and had established a Democrat-supporting newspaper in 1879. Scott was disillusioned with the Republicans' approach to national and state issues, arguing that the party wanted to maintain their political ascendancy above all else. Writing in 1882, he opposed the Republicans’ efforts to “centralize the government, its protective tariff policy...it builds up the few at the expense of the many, because it fosters monopolies of all kinds...”xi

It must be remembered that many of these more conservative African Americans had initially supported the Republican Party. Indeed, a conservative streak had run through much of black political activity in the early years of Reconstruction, even among the non-elite. Shortly after the end of the Civil War, black Alabamians met in Mobile, the majority of whom were clergymen. The delegates to the Mobile convention had been selected by meetings held across the state, so were, to a point, a representative group. The tone of the Mobile convention was summered up when the delegates called for "peace, friendship, and good will toward all men - especially toward our white fellow-citizens among whom out lot is cast," as well as acknowledging the "new obligations" they now faced to be good citizens. Moderation was therefore the order of the day. ${ }^{\text {xii }}$

As Reconstruction waned in the South, so too did support for the Republicans from some of these more conservative African Americans. Virginian Jesse Dungee, a Baptist clergyman from Richmond, provides a useful case study here. Dungee had originally served as a Republican in the Virginian House of Delegates in the early 1870s before becoming a Democrat in 1876. In an open letter to the leading white 
daily in the state, Dungee outlined his disillusionment with the Republican Party. He was fed up with the way in which they had been used as "political tools" and the way this fostered hostility between whites and blacks. In addition, he blamed the Republicans for the financial mismanagement of state finances, and implicated them in the failure of the Freedmen's Bank some two years earlier.

Dungee thus focused on economic issues pertinent to both African Americans as a group and as fellow Virginians to win over his audience. He believed that the best way forward was for black Virginians to "make full and manly reconciliation” with southern whites. ${ }^{\text {xiii }}$ Moreover, in order to gain some kind of credibility among black Virginians, Dungee even claimed in the letter that he had once been a slave. He was, in fact, freeborn, but his attempt to appeal to former slaves is revealing for it was an attempt by a black Democrat to try and counter their elitist image; one they could never quite shake off. ${ }^{\text {xiv }}$

Disillusionment with the Republican Party was a clear motivation for some, and as Dungee implied in his letter, reconciliation with southern whites was required. In the months after the Compromise of 1877, the political deal brokered in Washington that officially ended Reconstruction in the South, the northern press regarded black Democrats as harbingers of peace, "breaking” the colour line in the South. This desire for peace was made evident in a number of southern states. In South Carolina, for example, the restoration of "home rule" following the election of 1876 witnessed the election of southern paternalist Wade Hampton as governor. Hampton recruited a number of African American men to join his Red Shirts during the election campaign with the promise of peace. The black Red Shirts are an exception to the elitist profile set out earlier for the majority were poor, black farmers who had been slaves. Echoing the sentiments of Dungee, the Hampton campaign 
stressed that African Americans were southerners, too, with “a common love of land and place.” $\mathrm{xv}$

The desire for interracial harmony often went hand-in-hand with disillusionment with the Republican Party. Black Tennessee lawyer and ex-slave Alfred A. Froman, for instance, argued that since the Republican Party had abandoned African Americans, the only option left to them was to work with southern whites. It was “nonsense,” wrote Froman in January 1885, that African Americans “being poor, dependent, uneducated, should be trained to disregard their interest, and to wield their votes against the very men from who [sic] they get employment, only for the sake of being called a Republican.”xvi It was in African Americans’ best interests, reasoned Froman, they not only work with southern white Democrats, but chose to vote for them, too. This was echoed at a black Democratic conference held in Montgomery, Alabama, in 1892. As one of the conference's resolutions stated: "For a Negro to vote against these men, would be for him to go against himself; to vote with these men would be to go for his own interest, and to down race prejudice and race antagonism.”xvii

Yet there is another common trend in all the examples noted here: African Americans had to instigate such peaceful relations, not southern whites. The white press encouraged this. “Colored democracy of Lafourche! Wake up, organize your clubs, and with the aid of our good citizens go to work and secure the exercise of your rights," shouted one white Louisianan paper, "so that in November next you may contribute in restoring peace, order, and prosperity in our land of promise.”xviii African Americans were thus central to restoring peaceful relations, so thought whites, for they were the very group who were having a destabilizing effect on 
southern politics. Indeed, promises were made that those African Americans who formed and joined such clubs would be protected in their rights. ${ }^{\text {xix }}$

As this reveals, black clubs were encouraged by whites to help mobilise the black vote. Such clubs had been in existence since the time that the freedmen gained the right to vote. In August 1868, during the presidential election campaign, and the first in which black southerners could vote, a Democratic meeting was held in a theater in Montgomery, Alabama. This was a biracial meeting: African Americans delivered speeches in support of the Democrats, and were members of the state's Colored Conservative Club. In a highly ritualised way, echoing what they experienced in church, a number of black men walked up to the stand to be converted, adding their names to the party faithful. Music was performed at the event by a black band, a common feature of such occasions. ${ }^{\mathrm{xx}}$ The majority of African Americans, however, voted the Republican ticket in the presidential election that fall.

Four years later, a Greeley and Brown Club was founded in the city. Believing that the Liberal-Republican ticket (a national coalition of disaffected Republicans and Democrats led by Horace Greeley of the New York Tribune) would be the best means for African Americans to be secure in their rights, the resolutions passed by this club, reprinted in full in the leading white daily, affirmed their loyalty to the South and that common interest united white and black southerners. The men associating with this club used the language of the Republicans against them, making reference to the alleged subversive nature of the Union League, the Republican clubs in the South that politically mobilized African Americans. The last of the Greeley and Brown Club’s resolutions revealed both black and white Democrat concerns: "we oppose all secret organizations for political purposes, or any party that slanders or proscribes men because of their party principles.”xxi The naivety of these men is all too apparent here, 
given the far more extensive use of intimidation and outright violence used by white Democrats against black Republicans.

Black Democratic clubs would become most extensive in the state elections that ended Reconstruction in a number of southern states in the mid-1870s, most notably in Alabama, Mississippi and South Carolina. A good case study of the symbolic power of these clubs, however, can be found in Mississippi. In the election year of 1875, African American members of these clubs were able to take part in processions held during the election campaign. Pledges were made that they would be protected from black Republicans and secure in their employment. Flags, badges and uniforms, among other paraphernalia, were distributed freely to members. The badges also became a means of defence or a means of 'bossing' other African Americans, as in the case of some members of the Democratic club in Lafayette County. In addition, some African Americans would be invited to social events like barbeques and picnics, usually to perform in bands, but at other times to speak, either on request or voluntarily. Since black men were not allowed to address the more formal state conventions, this became the only means by which they could contribute to the political discourse. So while black Democrats could not, by and large, take part in the running of the party behind the scenes, whites gave these men the opportunity to contribute in public, in both active and passive ways. Yet this reveals tokenism on the part of white Democrats, and the limited options for political determination on the part of African Americans. What mattered for white Democrats was their presence: to contain or control, once again, the political engagement of black men. What mattered to black Democrats was their presence at such events: it was one of the few avenues open to them for political engagement in the public sphere. ${ }^{\text {xxii }}$ 
Speaking at such events continued into the 1880s. In Alabama, for example, William Councill, one-time Republican turned Democrat, actively campaigned for the Democrats in the 1880 election, becoming a "stump speaker" and supporting them in his newspaper. Councill was not alone in his support in Alabama. African American lawyer James A. Scott, the editor of another black newspaper in the state, the Birmingham (later Montgomery) Advance, also supported the Democrats. Scott had been a Democrat since the mid-1870s and was one of the few African Americans to attend a Democratic state convention. At the 1880 election he declared that the Republicans were no longer the same party of Lincoln - the political world of emancipation had gone. What Scott was implying here was that African Americans had to adapt to the changing political environment. ${ }^{\text {xxiii }}$ Such a view was echoed six years later in an anonymous letter to the Huntsville Gazette. The only reason some blacks voted for the Democrats, the correspondent argued, was because of their disillusionment with the Republican Party over its sincerity towards upholding black rights. ${ }^{\text {xxiv }}$

Indeed, at the national level, the 1880s was a decade of political change. In 1884 the Democrats won the White House with election of Grover Cleveland. In the run up to the election, the Colored Citizen, a black newspaper based in Montgomery, Alabama, pointed out that if the state Democratic Party would assure blacks that their vote would be counted fairly, African Americans would consider supporting them. The ultimate goal for both sides, the paper contended, was for more friendly relations between white and black southerners. ${ }^{\mathrm{xxv}}$

\section{LYNCHBURG CONVENTION}


Cleveland's administration was influential in making some African Americans more amenable to the Democracy. When the Lynchburg convention met at the end of September 1885, it set out to present itself as an opposition meeting to the Republican Party, and thus translate changes within the national political climate to a local context. Its target was the state’s Republican leader, former Confederate William Mahone, who they believed represented a divisive past and who was not helping black Virginians in their efforts to promote harmonious race relations. Those present at Lynchburg including freeborn John B. Syphax, from Arlington, who was a member of an influential black family in Washington, D.C., and Rosier D. Beckley, who held a federal position in Washington, D.C. In his address as chairman, Beckley stressed how the gathering was not affiliated to any political party but stressed the need for African Americans to think for themselves unhindered by party loyalties. ${ }^{\text {xxvi }}$

While the convention made it clear that they were not a Democratic convention, not everyone saw it that way. A correspondent to the New York Freeman, who wrote regularly from Norfolk, Virginia, regarded those present as “Colored Democrats”, unrepresentative of black Virginians at large. Indeed, the Lynchburg convention was generally dismissed as a talking shop for disgruntled office-seekers. The African American Richmond Planet, noted:

We repudiate the actions of the "Colored Convention" recently held at Lynchburg so far as it professed to represent the colored people of this State. It was nothing more nor less than a few men who represented nobody but themselves, and who were in the pay of the Democratic bosses. We know whereof we speak and are prepared to substantiate what we say.

George Freeman Bragg, editor of the Republican-supporting black newspaper, the Petersburg Lancet, echoed such a view. The convention had been representative to a 
point, he pointed out, but it had been "burdened with retired politicians who have pretty much outlived their usefulness and remain barnacles and impediments to the progress of the race.” While the address was "sensible in many respects," he thought it "indicative of the disappointment and hard luck of some unfortunate colored politicians who sadly regard dealing in politics the means of earning a living."xxvii

The lack of patronage was always a sore point among many southern black Republicans, and became more pronounced with the rise of the 'lily-white' Republicans in the 1880s. These were Republicans who split away from the biracial coalition that had been created in the South during Reconstruction and created a whites-only party as a way to attract more support from southern whites. In some cases, Democrats gave patronage to their black supporters. In Norfolk County, Virginia, for example, African Americans who had supported the Democrat Fitzhugh Lee for governor in the 1885 election were offered political positions. T. Thomas Fortune, the editor of the African American newspaper, the New York Age, made an example of those black Virginians who had supported Lee, considering this evidence that African Americans “were losing confidence in the politicians' and 'relying more and more upon their own discretion and leadership.”xxviii

Fortune was the leading black voice in the 1880s calling for African Americans to vote independently, articulated in his 1884 book entitled Black and White. This was following in the wake of a relatively small but vocal group of northern black leaders who in the 1870s had begun to question the Republican Party's commitment to defending the rights of African Americans. Fortune was one of many younger black leaders who had emerged by the 1880s, challenging African Americans' attachment to the Republican Party, and calling for black self-determination in politics. ${ }^{\text {xix }}$ 
Fortune became a forceful proponent of seeking political alternatives, however even he had lost faith in the Democrat's commitment by the end of the 1880s. As he wrote in the New York Age in January 1891:

Whenever the question is reduced to 'shall the Negro enjoy his full rights under the Constitution?' only the mercenary Negro will be found in the future on the Democratic side of the fence in national and congressional elections. ${ }^{\mathrm{xxx}}$ Despite an attempt to revitalize the political debate in the 1880s, Fortune's attempts to encourage African Americans to vote without loyalty to a particular party never really materialised in any meaningful way. He never grasped the local complexities of black politics in his efforts to recreate southern politics in the image of the North. It was one thing to vote for the Democrats in the North, where African Americans were able to vote relatively freely, but quite another in the South. ${ }^{\text {xxxi }}$ Moreover, the southern Democrats could not mobilize black voters in the same way as the Republicans.

Black Democrats were therefore always a minority, especially in the South. In response to another convention call by black Democrats two years later, to be held in the Virginian town of Danville, the Weekly Pelican of New Orleans dismissed the notion that black Democrats were prolific, at least in Louisiana. "The Negroes of Louisiana have no desire, nor do they propose, to join the party of treason and political disfranchisement.” It added: “They have no desire to nest with the Democratic party - the party of midnight raids and election frauds.” ${ }^{x x x i i}$ This was a particularly pertinent comment given that Danville had witnessed a racial massacre some four years earlier that had brought an end to state control by the Readjusters: a different kind of “independent” politics that consisted of a biracial coalition of disaffected Democrats and black Republicans. 
That members of the Virginian black elite, like John Syphax, chose the independent route suggests an inherent elitism in the state's black political independence movement. This movement reached its peak in Virginia in September 1887 when Rosier D. Beckley, a leading figure at the Lynchburg convention in 1885, and other black Democrats, formed the Independent Club of Colored Virginians. This followed the holding of another black convention which had met in Danville in April 1887 “to organize the Negro vote into an independent political power,” voting for those who would "agree to advance the industrial interests of the race." xxxiii There was growing sentiment against the white Republican boss, William Mahone, and the club fed into this opposition.

Based, initially, in Washington, D.C., the club’s objectives included an upholding of black rights, an end to prejudice (including a veiled criticism of Mahone's tactics), and a demonstration of the core differences between the Republicans and Democrats. The club’s manifesto warned of the danger of a Republican victory in the state and declared the group would assist the Democrats to victory in the forthcoming state elections. By assistance, it meant delivering the black vote to the Democrats. ${ }^{\text {xxiv }}$

The Washington Bee thought the club 'peculiar' and had short shrift for Beckley. It regarded him as a failed office holder, who had switched from the Republicans to the Democrats in order to obtain patronage in Washington, and had then fallen out with the Democrats when they failed to recognise him. It is likely that Beckley wanted a promotion, for he had been appointed as the Democratic Doorkeeper of the House of Representatives in January 1884, and no evidence has been found to suggest that he had been promoted since then. ${ }^{\mathrm{xxxv}}$ The Bee was also keen to point out that Beckley had no support in the Old Dominion, and that the other 
members of the club's committee were unknown. The main point the Bee wished to stress, however, was to ask how any African American could support the Democrats after what had happened at Danville four years earlier, when a massacre of African Americans had taken place in the town which influenced the state election in favour of the Democrats. ${ }^{\text {xxxvi }}$ Two years later the paper wondered out loud what the state Democratic boss really thought of men like Beckley. ${ }^{\text {xxvii }}$

The black press therefore picked up on the important issue of patronage, where opportunities to gain federal patronage in Washington had emerged as a result of the new Democratic administration. The creation of black Democratic clubs in Washington, D.C., for instance, would have influenced black Democrats in Virginia. Richmond's proximity to the capital meant that it was influenced by political trends emanating from there, and is an example of how Virginia's political situation was unique to the South.

Supporters of the Democratic President, Grover S. Cleveland, founded one such club in Washington, the Colored Club of Ward 11. At its conference in 1885, the committee of resolutions noted how "designing politicians” had stirred up the rumour that the election of a Democratic president would turn back the clock for blacks, and stated that Cleveland had so far done more to remove the colour line than any other president. ${ }^{\text {xxxviii }}$ It is interesting that the language used here, such as “designing politicians,” was similar to that used by the opponents of black Democrats.

The club would have gained some support from the city's black elite, made up of the "old families" whose members had been largely free before the war, and were influenced by upper-class white society in their lifestyle. ${ }^{\text {xxxix }}$ Family background was all-important to this group, founded on the antebellum experience - "their place in the slave system, their role in opposing it, and the extent to which their families had been 
free from it." ${ }^{\mathrm{xl}}$ Education was one defining feature of the group, but this was more noticeable in the rising middle class rather than of the elite, whose intimate experience of slavery was often a few generations removed. That such a group made up much of the nationally known and the state black leadership is perhaps no surprise, with their sense of noblesse oblige. Their involvement in the cause for equal rights demonstrated "their access to the white power structure," while they demonstrated through their lives the possibilities of black uplift. ${ }^{\text {xli }}$ This symbolism was a feature of all black leaders, however the distance between the elite and the black masses was often considerable, and made black Democrats' efforts at garnering wider support that much harder.

The close relationship which black Democrats wished to establish with the “better class” of whites reflected a change in what black leaders held to be qualifications for citizenship, which itself was a reflection of broader, white notions of what constituted American citizenship. As Kevin Gaines points out, the move from the earlier "unconditional claims" to citizenship advocated by black leaders during Reconstruction to the conditional claims of "racial uplift" by the end of the century, revealed an "intraracial division" between lower and upper class blacks. Such an uplift ideology therefore legitimized the black elites' claim to citizenship, because they considered that they had earned such rights. This “bourgeois evolutionism” regarding African American claims to citizenship was argued by many black leaders by the 1890s, exemplified in the accommodating strategy pursued by Booker T. Washington, the Alabama-based leader and head of the Tuskegee Institute. Yet a study of black Democrats before the 1890s reveals a similar strategy. This rested on what another historian has referred to as the "Good Negro" strategy of appealing to the white elite, whereby 
the black elite contrasted themselves with the more militant and less deferential “Bad Negroes”. However, political participation in the public sphere was still possible in the 1880s, which is why some black conservatives advocated support for the Democrats. By the 1890s, the "racial uplift" ideology advocated by black conservatives was distinctly non-political, reflecting the diminishing opportunities for African Americans to participate in southern politics. ${ }^{\text {xlii }}$

Black Democrats, as with other members of the black elite, can hardly be said to be representative of the majority of African Americans in the South in this period. Without a mass following from the black non-elite, therefore, black Democratic clubs in Virginia and elsewhere never gained the same kind of foothold as did their Republican counterparts, even if they began to organize at a national level. In the South, black Democratic clubs were derided in the black press. ${ }^{\text {xliii }}$ The lack of support for the Democrats can be explained, in part, by the growing disillusionment among black Democrats. The black press picked up on this:

The average Negro Democrat looks seedy. He is usually attired in a threadbare suit and wears a wornout [sic] expression all over him. He smells like a distillery, too. He has a lend-me-a-quarter look in his eyes. What's the matter? He boasts of the richness of the Democratic vineyard. They forage, he tells us, on the fat of the land. Then why should he look so hungry and lean and demoralized? The Negro Democracy should brace up and resolve to be a $\operatorname{man}^{\text {xliv }}$

Yet by far the most significant reason for the lack of black support for the Democrats was the result of Republican opposition to them: most prominently, from black women and the church. 


\section{OPPOSITION TO BLACK DEMOCRATS}

From the moment African Americans gained the vote in the late 1860s, voting for the Republican Party became something of a religion, both figuratively and literally, as revealed by Democratic meeting held in the Montgomery theater. Southern black leaders picked up on this. Writing during the election campaign of 1892, the black Virginian lawyer James Hayes thought it high time that black voters should be allowed to vote for whomsoever they chose. He noted how any deviation from the Republican Party was regarded as sinful. Choosing to support the Democrats carried the real risk of social ostracism, no matter who you were: a situation more acute in the South as it ever was in New York or even Washington, D.C. ${ }^{\text {xlv }}$

Oppostion to black Democrats was most prominent within the political space of the church. Jesse Dungee, targeted those black clergy who opposed him, labelling them “Radicals”. 'Why do they use their churches for such unholy purposes,' asked Dungee, 'and then pretend that they have nothing to do with politics?' By way of reply, one black clergyman stated that Dungee’s “denominational tenets” had made him "unpopular." xlvi Another clergyman stated that he was a liar, his labelling of specific ministers as “malicious;" adding, with a note of sarcasm:

Sir, does it not seem to be a little strange that the learned, wise, and reverend gentleman should take such a course as this to get himself into the favour of the white people of this city? Does he think that the white people of this city are so ignorant that they do not know a hypocrite when they see him? If he does, he is very much mistaken, for there are high, respectable people in this city that had rather have a dog in their presence than a hypocrite, be he white or black. ${ }^{\text {xlvii }}$ 
The politics of the black church was such that anyone who deviated from the Republican fold was either reigned in or removed. Dungee, for instance, was eventually driven from his church: whether he was forced to or whether he simply abandoned his congregation, is open to debate. One black Republican newspaper which covered Virginian affairs seemed to imply the latter. In a letter to the People's Advocate, a correspondent regarded Dungee as a passionate orator, although regarded his lack of education as a cause for his speeches being rather hit or miss affairs. Dungee’s “moral strength” was questioned also, a claim supported by the reaction to Dungee's comments on his fellow clergymen. He was also considered to be indecisive and lazy, although he was singled out as better than the average Black Democrat. The Democrats had not gained anything by bringing Dungee into their fold, the correspondent thought, whereas the Republicans had lost a potential leader. ${ }^{\text {xlviii }}$

This kind of ostracism continued throughout the 1880s. Charles Gordon, a black clergyman from Petersburg, Virginia, was ostracised for opposing the two Republican candidates in the Fourth Congressional election in 1888. It was reported by the Richmond Planet following the election that there was "much dissatisfaction" from other ministers with Gordon, for he had "voted the Democratic ticket or failed to support the Republican ticket”. Gordon admitted this to be the case, stating (so it was reported), "that they [fellow black ministers] were persecuting him on account of his politics”. Gordon tried to split away from the church, and take supporters in the congregation with him, but with little success. This affair does have echoes with Dungee's attempts to break away from the Republicans in the mid 1870s, and the hostility towards him that such action provoked. ${ }^{\text {xlix }}$ This was not unique to black conservatives in Virginia: members of the Missionary Baptist Corner Stone Church in 
Arkansas, for example, dismissed its clergyman, James Fleshman, after it was proven that he had voted for the Democrats. ${ }^{1}$

Ostracism was often closer to home. African American women were central to the policing of the black vote, ensuring that black men maintained their loyalty to the Republican Party. Considerable evidence for this can be found from Reconstruction onwards. Black women not only asserted themselves politically as church members, but in some cases clubs were formed, where women pledged that they would leave their husbands if they voted the Democratic ticket. Influencing how black men voted went beyond the home, such as during an election campaign in Alabama in 1874 . After a black Democrat interrupted an outdoor Republican meeting outside Montgomery, Alabama, by declaring that the Republicans were lying to them, a number of women hurled a volley of verbal abuse towards the individual. Violence was only prevented when a white planter intervened and advised the Democrat to leave. Charles Nordoff, travelling through the state the following year, was told of incidents whereby Republican candidates would ask black women if they would leave their husbands if they voted for the Democrats. ${ }^{\text {li }}$

Scenes like these were prevalent in other states and reveals the political action black women would take if necessary. Speaking before an 1884 Senate hearing investigating the Danville massacre in Virginia the previous fall, Violet King outlined what action she would take if her husband were found to be a Democrat. "I would just picke [sic] up my clothes and go to my father's, if I had a father,” she told the committee, “or would go to work for 25 cents a day”. King repeatedly made the point that if a black man were found to have voted for the Democrats, they would have “sold” themselves: the legacy of the slavery therefore underlay any black support for 
the Democrats. ${ }^{\text {lii }}$ Such a view was reinforced twelve years later by African-American teacher and activist, Anna Julia Cooper:

[T]he black woman can never forget - however lukewarm the party may today appear - that is was a Republican president who struck the manacles from her own wrists and gave the possibilities of manhood to her helpless little ones; and to her mind a Democratic Negro is a traitor and a time-server. What these examples of ostracism demonstrate is the significance of the vote to African Americans. For black women, when black men went to vote, they were voting for them, too. African American women were demonstrating their own agency in political affairs, even if indirectly. The extent of this can be summed up well in Frances Ellen Watkins Harper’s poem, “Deliverance”:

Day after Day did Milly Green Just follow after Joe, And told him if he voted wrong

To take his rags and go.

That such agency could be expressed in poetry reveals the extent of it: the audience of the poem would have been aware of its existence in order to understand the reference.

The vote therefore held great symbolic value for African Americans: power to assert themselves as citizens when political office and economic advancement were not easy to come by. Women questioned the manhood of men who voted for the Democrats and classed them as traitors. The Republican black press often reinforced such messages. Following the defeat of the Readjusters in Virginia in 1883, the Petersburg Lancet blamed black Democrats for their defeat, calling them “dirty” and “scurrilous,” as well as “renegade colored men.”,liii 
Yet even those black Democrats who were prepared to renounce their party loyalties could be brought back in to the fold. In the late summer of 1888, the “leading colored Democrat of the South,” L. A. Martinet of New Orleans, resigned as editor of the Democratic newspaper, following a period of acute racial tension in the Pelican state. His letter was published on the front page of the Louisiana Standard, edited by black Republican T. B. Stamps, who referred to Martinet as "scathingly and manfully denouncing” the Democratic response (or lack thereof) to the recent massacre of African Americans in Iberia Parish. Martinet’s letter suggests the inevitability of disappointment that black Democrats faced concerning the commitment of their fellow whites. As Martinet summed it up succinctly: "our efforts to establish and maintain peace and harmony between the races have, it seems to me, not only proved futile, but may be, under the circumstances, considered officious.”liv

\section{CHANGING POLITICAL CLIMATE}

By the 1890s, the dynamics of southern political culture changed considerably with the Populist insurgency. Disillusioned non-elite whites sought to gain power over the mainstream state Democratic Party, with the assistance of black Republicans. Their efforts to woo black voters succeeded in some cases, such as North Carolina. In Alabama, their efforts backfired on them. The miners' strike of 1894, more than any other event, led many black Alabamians to support the Democrats in that year's gubernatorial election, and resulted in the election of Democrat William C. Oates to the Governor’s Mansion. The Republicans were so divided that they did not put forward a candidate for the office, but rather the lily white faction supported the Populist candidate. $^{\text {lv }}$ 
The question to ask is that why, in a time when the Populists were at the peak in the state, did black voters support the Democracy? Or was this a case of mass fraud? Fraud was certainly charged at the Democrats, and it is more than likely that it did take place on wide scale, despite claims to the contrary. ${ }^{\text {lvi }}$ What is of interest is that the charges of fraud were systematically challenged. The Democrats were on the defensive, but also wanted it to make clear that the Populists were not as pro-black as some thought, at least in Alabama. For a start, the black and tan faction of the Republican Party, led by William Stevens, refused to support the Populists, with Stevens in the end voting for Oates. ${ }^{\text {lvii }}$ More significant, however, was the support offered by many local black leaders who played a crucial role in Oates gaining widespread black support. The unease with which other black leaders (aside of Stevens) held the Populists was revealed both privately and publicly. Even before the 1894 election, local black leader Jerry B. Blevins wrote of the Populists as "latter-day Confederates.”viii However, in 1894, it appears that the black clergy played a greater role than the established black political leadership in swaying the black masses. A number of the clergy publicly supported Oates’ candidacy and told their congregations to vote accordingly, some of them also making speeches in favour of Oates. ${ }^{\text {lix }}$ It was claimed by Oates that he received some 25,000 black votes in that election. Moreover, the violence surrounding a recent miners' strike in the state encouraged further the black swing to Oates. Oates spoke against the strikers and declared that if elected Governor he would ensure that African American rights were protected. "These sentiments were applauded loudly by the colored voters present at place where he spoke,” Oates later wrote, oddly in the third person, "and it is a notorious fact that a greater number of colored voters at that election voted for him than ever voted for any democrat in the State prior thereto.” 
Virginia’s gubernatorial election of 1893 witnessed a similar turn by some African Americans towards the Democrats as an act of political expediency. The Negro Democratic League was at the forefront of encouraging black support for the Democratic candidate, Charles T. O’Ferrall, arguing that it was best for Virginian blacks to support "that class of white people that own and control everything." "xi It is hardly surprising that the Democrats received an increase in black support, given the virtual non-existence of the Republican Party and the racist overtones of the Populists. As historian Charles Wynes succinctly puts it, the League’s resolution was “political despair speaking through the voice of economic expediency.”,

As these examples from Alabama and Virginian demonstrate, choosing the Democrats over the Populists was simply siding with the lesser of two evils. Yet for some, supporting the Democrats continued to be about obtaining political patronage, and elitist. The Populists certainly held this view. As their national publication noted, somewhat sarcastically:

The Negro democrat is a source of inspiration and joy to all who know him. He holds an office. Of course he does - that's what he came for...The Negro democrat cares nothing for the poor and oppressed for his race. He treats the black laborer precisely as the white office-holder treats the white producer with gushing fondness during the campaign and with contemptuous indifference after the election. ${ }^{\text {xiii }}$

Nevertheless, some in the black press did praise the actions of black Democrats. The most notable example was H. Clay Smith of Alabama, whom the Bee lauded as “a good politician and one of the most highly educated negroes from the south.” While not one of the long-standing patronage seekers that newspapers such as the Bee usually assailed, given that he was only 38 in 1893, he did have the support of the 
recently re-elected president, Grover Cleveland. Smith was rewarded for such loyalty through his appointment to a federal position in Brazil; an appointment Smith later told Cleveland demonstrated that African Americans were being recognized by the Democratic administration. $^{\text {lxiv }}$

By the end of the 1890s, calls were made on black Democrats to influence those white Democrats they helped to elect. Following the 1898 state elections in North Carolina, a correspondent to the Washington-based Colored American called on both black Democrats and “conservative Negro educators” to influence those Democratic members of the state legislature they had supported. The paper noted that one area they had to exert influence was over the introduction of railroad segregation. Such laws were already in place in the majority of southern states, except for the old Atlantic seaboard states like North Carolina, South Carolina and Virginia. The correspondent thought that black Democrats "owe it to themselves, their relatives and to the Negro race in the state, to see to it, that the democrats...do not put into operation...the infamous 'Jim Crow car' system."

The fact that black Democrats could not prevent "certain white men" from pushing for the introduction of Jim Crow segregation reveals the limited returns for African Americans supporting the Democracy. Moreover, while the location of the aforementioned correspondent to the Colored American is unclear, the letter is made all the more extraordinary given the extensive violence surrounding the state election that year. The worst violence occurred at Wilmington, North Carolina, where a racial massacre took place. The implication of trying to influence the recently elected white Democrats to the state legislature appears to be a last-ditch attempt to try and check the 
worsening racial climate in North Carolina, whereby the political avenues open to African Americans were becoming ever-narrower. ${ }^{\text {Ixvi }}$

The example of North Carolina reveals that for some African Americans, making the best out of a bad situation and simply holding on to what they had already gained from the Reconstruction era was their primary aim in politics. As this essay has revealed, this led a certain segment of the southern black public to support (or at least consider) the Democratic Party. Given the fact that African Americans had been disenfranchised in the majority of southern states by the end of the century, or facing the imminent prospect of such a situation, black Democrats by the 1890 s were clearly fighting a loosing battle. Such a battle, they believed, needed to take place on the inside. The symbolic nature of black political leadership is revealed here, something that had clear implications for the political engagement of others. This appears less in protecting African Americans' full political and civil rights, and more about finding areas of potential compromise. A crucial question considered by black Democrats was, therefore, whether it was better to have one black man working with whites than have none at all.

Yet, the symbolic nature of black leadership did transcend party lines, which suggests that this was a feature of black leadership more generally. This can be seen with the equally conservative (although Republican) Booker T. Washington. As revealed earlier in this essay, the dividing line between black Republicans and Democrats was not always as clear-cut as perhaps has been assumed, given the relative ease with which men such as Jesse Dungee moved from the Republicans to the Democrats. Even so, such a course had consequences: not least in giving the wrong impression to whites that African 
Americans were content with their situation, and thus ultimately selling African Americans short, politically.

Self-interest certainly played a role here, as it does for any individual taking on a leadership role, yet did self-interest play a more prominent role in the decision-making process of black Democrats? Class considerations are important factor here, and the degree to which economic possibilities enabled political participation often rested on geographic location. While it was easier for northern blacks to support the Democrats, there were also intra-regional divisions within the South, not to mention urban-rural differences. It is no coincidence that black Democracy was able to emerge to the extent that it did in urban areas of the South, where African Americans were less tied economically to white landowners.

\section{CONCLUSION}

The key aspect of black independent politics in the 1880 s was the varying degrees of hostility shown towards it from black Republicans. African Americans not only chose to support the Democracy, and that Republican votes were lost, but their numbers were sufficiently large to warrant a sustained response from their Republican counterparts. However, it would be an error to say the Democrats captured anything like a meaningful number of black votes honestly. Bribery and coercion were their main tools of gaining votes, not to mention electoral fraud in all its guises.

This being said, we still need to investigate in a systematic way the extent of black Democratic support, for it would be an error to simply dismiss the significance of the political independence movement of the 1880s, with its call for 
African American men to consider supporting the Democratic Party. Black agency needs to be explored to its full extent, to try and read between the lines of the Republican and Democratic sources. Either because of genuine conviction or political opportunism, southern black Democrats believed that turning away from the Republican Party meant a more secure future; both socially and economically. While comments by black Democrats might appear naïve, they themselves thought black Republicans were as naïve, thinking that their party cared for African Americans any more than the Democrats.

While self-interest provides a motive for any political activity, it was even more of a consideration for black Democrats. This is perhaps best summed up by those clergymen who supported the Democrats, for it is clear that the majority of their congregations disagreed with their political point-of-view. Given the significance of the black church in the political mobilization of African American voters, black Democrats could never hope to be as representative of the broader black public than their Republican counterparts. As a result, this lack of representation, and therefore black constituency, meant that the leadership position of black Democrats was always going to be unstable and unsustainable.

The phenomenon of black Democracy should perhaps not surprise us if we take a broader view of black agency. Agency is about self-interest: it does not necessarily follow that it will benefit others. Yet black Democrats considered that they were taking the longer view, considering that the only way to influence the political situation was to act from within the system. Given the nature of white racial attitudes in the late nineteenth century, this seems naïve at best; a shortsighted approach that reveals the desperation of these men in their efforts to counter their perceived political emasculation by whites. 
If we put aside the motivation of white Republicans and Democrats, what perhaps is more significant is that such a debate over political participation could be held at all in the post-Reconstruction South. For some, this meant working with a less-than-enthusiastic Republican Party. For others, it meant renouncing the Republican Party altogether. Southern black Democrats were an important feature of African American political culture in this period; for, if anything, they demonstrate the remarkable vitality of black politics in the public sphere, both male and female, in the post-Reconstruction South.

\footnotetext{
${ }^{\mathrm{i}}$ Virginia Lancet, October 10, 1885.

ii Ibid.

${ }^{i i i}$ My thinking on this has been influenced by Walter Johnson's work on rethinking slave "agency”. See his article "On Agency,” Journal of Social History 37 (Fall 2003): 113-124.

iv The terms "Conservative" and "Democrat" are used interchangeably in this essay, as they were by contemporaries to differentiate from the "Radicals" (Republicans). ${ }^{v}$ Walter Lynwood Fleming, Civil War and Reconstruction in Alabama (New York, 1905); There is little scholarship that focuses solely on black Democrats. The main examples are: August Meier, “The Negro and the Democratic Party, 1875-1915," Phylon 17 (1956): 173-91; Lawrence Grossman, The Democratic Party and the Negro: Northern and National Politics, 1868-1892 (Urbana, 1976); Randall B. Woods, "C.H.J. Taylor and the Movement for Black Political Independence, 18821896,” Journal of Negro History 67 (Summer 1982): 122-35; Joel Williamson, After Slavery: The Negro in South Carolina during Reconstruction (1965; rpt. Chapel Hill, 1975), 342-43, 350-353, 406-412.

${ }^{v i}$ Edmund Drago, 'Hurrah For Hampton!' Black Red Shirts in South Carolina during Reconstruction (Fayetteville, AK, 1998); John Giggie, "Disband him from the church': African Americans and the Spiritual Politics of Disfranchisement in PostReconstruction Arkansas,” Arkansas Historical Quarterly 60 (2001): 245-264 vii Drago, 'Hurrah for Hampton!'; Johnson, “On Agency,” 116.

viii A visual representation of this intimidation can be found in Harper's Weekly, October 21, 1876.

${ }^{\text {ix }}$ For the differences between those forced to vote for the Democrats and those who chose to, see: Nell Irvin Painter, Exodusters: Black Migration to Kansas after Reconstruction (1976; New York, 1979), 13.

${ }^{\mathrm{x}}$ W.E.B. Du Bois, Black Reconstruction: An Essay toward a History of the part which Black Folk played in the attempt to Reconstruct Democracy in America, 18601880 (1935; rpt. New York, 1956), 612.

${ }^{x i}$ Eric Foner, Reconstruction: America's Unfinished Revolution, 1863-1877 (New York, 1988), 546; Blount County Democrat, 29 Apr. 1882, quoted in Samuel Shannon, “Tennessee,” in Henry Lewis Suggs, ed., The Black Press in the South, 1865-1979 (Westport, CN, 1983), 313-355 (quotation on 321).
} 
${ }^{x i i}$ Peter Kolchin, First Freedom: The Responses of Alabama's Blacks to Emancipation and Reconstruction (Westport, CN, 1987), 152-53 (quotations on 153). xiii Eric Foner, Freedom's Lawmakers: A Directory of Black Officeholders during Reconstruction (New York, 1993), 67; Richmond Dispatch, August 9, 1876.

${ }^{\text {xiv }}$ Richmond Dispatch, August 9, 1876; Foner, Freedom's Lawmakers, 67. See, also, Jack P. Maddex, The Virginia Conservatives: A Study in Reconstruction Politics (Chapel Hill, 1970), 197.

${ }^{\mathrm{xv}}$ Harper's Weekly, December 8, 1877; Drago, 32.

${ }^{\text {xvi }}$ Cleveland Gazette, January 3, 1885, quoted in Joseph H. Cartwright, The Triumph of Jim Crow: Tennessee Race Relations in the 1880s (Knoxville, TN, 1976), 59.

${ }^{x v i i}$ Montgomery Daily Advertiser, December 2, 1892, quoted in Horace Mann Bond, Negro Education in Alabama: A Study of Cotton and Steel (1939; Tuscaloosa, AL, 1994), 141; Washington Bee, June 10, 1893.

xviii Thibodeaux [La.] Sentinel, quoted in Frank Leslie's Illustrated Newspaper, August 29, 1868.

${ }^{\text {xix }}$ T. U. Bernard, First Vice-President of the Colored Democratic Club Number 1 (Mobile, Alabama), was praised by the white Democratic press for always being "true to the South.” The implication here, of course, that by only supporting the Democrats could any one in the South be "true" to the region. Mobile Advertiser and Register, April 20, 1867, quoted in Kolchin, 142; Iberville [La.] South, quoted in Frank Leslie's Illustrated Newspaper, August 29, 1868.

${ }^{\mathrm{xx}}$ Weekly Georgia Telegraph, August 28, 1868.

${ }^{x x i}$ Montgomery Daily Advertiser, August 8, 1872, reprinted in Herbert Aptheker, ed., A Documentary History of the Negro People of the United States, Vol. 2: From the Reconstruction Era to 1910 (1951; New York, 1968), 567-68 (quotation on 568); see, also, Weekly Huntsville Advocate, August 9, 1872.

xxii Vernon Lane Wharton, The Negro in Mississippi Politics, 1865-1890 (1947; New York, 1965), 185-87; Similar scenes occurred in Georgia and South Carolina: see Drago's Hurrah for Hampton, as well as his Black Politicians and Reconstruction in Georgia: A Splendid Failure (Baton Rouge, 1982), 147.

xxiii New York Sun, August 16, 1880; Montgomery Advance, September 11, 1880, quoted in Steven Hahn, A Nation Under Our Feet: Black Political Struggles in the Rural South from Slavery to the Great Migration (Cambridge, MA, 2003), 388.

${ }^{\text {xxiv }}$ Huntsville Gazette, September 25, 1886.

xxv (Montgomery) Colored Citizen, May 3, 1884.

${ }^{x x v i}$ Luther P. Jackson, Negro Officeholders in Virginia, 1865-1895 (Norfolk, VA, 1945), 41, 61; Richmond Dispatch, October 1, 1885.

${ }^{x x v i i}$ New York Freeman, October 10, 1885; Richmond Planet, quoted in Cleveland Gazette, October 10, 1885; No extant copies of the Planet from this period have been found, so the extracts reprinted by the Gazette are all that remain. See, also: Richmond Planet, quoted in Cleveland Gazette, October 17, 1885; Petersburg Lancet, October 10, 1885.

xxviii Petersburg Lancet, November 28, 1885. See, also, Cleveland Gazette, November 28, 1885; T. Thomas Fortune, The Negro in Politics: Some pertinent reflections on the past and present political status of the Afro-American, together with a cursory investigation into the motives which actuate partisan organizations (New York, 1886), 69, reprinted in Shawn Leigh Alexander, ed., T. Thomas Fortune, the AfroAmerican Agitator: A Collection of Writings, 1880-1928 (Gainesville, FL, 2008), 2773. 
${ }^{x x i x}$ T. Thomas Fortune, Black and White: Land, Labor, and Politics in the South (1884; rpt. New York, 1968); Shawn Leigh Alexander, An Army of Lions: The Civil Rights Struggle Before the NAACP (Philadelphia, 2012), 5.

${ }^{\mathrm{xxx}}$ Fortune quoted in Emma Lou Thornbrough, T. Thomas Fortune: Militant Journalist (Chicago, 1972), 103.

${ }^{x x x i}$ Black support for the Democrats was more noticeable in the North. See, for example, a speech made by T. McCants Stewart, during the Harrison presidency, supported the Democrats. The Afro-American in Politics: An Address, October 27, 1891 (New York, 1891).

xxxii New Orleans Weekly Pelican, March 19, 1887.

xxxiii Cleveland Gazette, April 2, 1887.

xxxiv Washington Bee, September 10, 1887.

xxxv Ibid.; Petersburg Lancet, January 19, 1884.

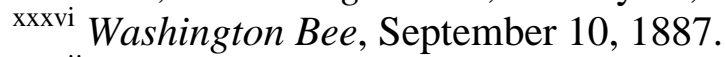

xxxvii Ibid., August 24, 1889.

xxxviii A Conference Held by the Colored Club of Ward 11, Washington, D.C., June 4, 1885, Grover Cleveland Papers, Series 2, reel 5, Manuscript Division, Library of Congress, Washington, D.C.

xxxix William B. Gatewood, Aristocrats of Color: The Black Elite, 1880-1920 (Bloomington, IN, 1990), ix-X.

${ }^{x l}$ William B. Gatewood, "Aristocrats of Color: South and North, The Black Elite, 1880-1920," Journal of Southern History 54 (February 1988): 3-20 (quotation on 5). xli Ibid., 7.

xlii Kevin K. Gaines, Uplifting the Race: Black Leadership, Politics, and Culture in the Twentieth Century (Chapel Hill, 1996), 21; Gregory Mixon, “'Good Negro-Bad Negro': The Dynamics of Race and Class in Atlanta During the Era of the 1906 Riot," Georgia Historical Quarterly 81 (Fall 1997): 593-621.

xliii For reference to the first National Democratic Colored Convention, see the Huntsville Gazette, August 4, 1888; For analysis of the national convention, see Randall B. Woods, "C.H.J. Taylor and the Movement for Black Political Independence,” 128. For a typical view of a black Democratic club, see Huntsville Gazette, March 10, 1888.

xliv Cleveland Gazette (quoting the Press), August 11, 1888.

xlv The Southern News, October 15, 1892.

${ }^{x l v i}$ Richmond Dispatch, August 10, 1876.

xlvii Ibid., August 15, 1876.

xlviii People's Advocate, August 12, 1876.

${ }^{x l i x}$ Quotations from the Richmond Planet, March 15, 1890, cited in Harold S.

Forsythe, "African American Churches, Fusion Politics in Virginia, and the

Republican Gubernatorial Campaign in 1889,” in John Salient, ed., Afro-Virginian History and Culture (New York, 1999), 222. The threat of expulsion for any member of a black church congregation not supporting Langston was common. William F. Cheek, "A Negro Runs for Congress: John Mercer Langston and the Virginia Campaign of 1888,” Journal of Negro History 52 (January 1967): 14-34 (quotation on 28).

${ }^{1}$ Richmond Dispatch, February 20, 1877; Giggie, "Disband him from the church," 245-46.

${ }^{\text {li }}$ Charles Nordoff, The Cotton States in the Spring and Summer of 1875 (New York, 1976), 88-89. 
${ }^{\text {lii }}$ Fleming, 776; for accounts of how black Republicans intimidated black Democrats see, for example, U.S. Congress, House, Affairs in Alabama, 43d Cong., 2d sess., H. Rept. 262, 151-55; Charles Nordoff, The Cotton States in the Spring and Summer of 1875 (New York, 1876), 9-10; New York Times, November 4, 1874; King quoted in Elsa Barkley Brown, "To Catch the Vision of Freedom: Reconstructing Southern Black Women's History, 1865-1880,” in Ann D. Gordon and Bettye Collier-Thomas, eds, African American Women and the Vote, 1837-1965 (Amherst, MA, 1997), 83. liii Anna J. Cooper, A Voice from the South (1892; New York, 1988), 140; Frances E.W. Harper, Sketches of Southern Life (Philadelphia, 1893), quoted in Gerda Lerner, ed., Black Women in White America (1972; New York, 1992), 249; Petersburg Lancet, November 17, 1883, quoted in Henry Lewis Suggs, "Virginia," in Suggs, ed., The Black Press in the South, 379-421 (quotation on 390).

liv U.S. Congress, Senate, Congressional Record, 50th Cong., 1st sess., Sept. 27, 1888, S Rept. 19, Appendix, 8989-97 (Martinet's letter can be found on 8993). ${ }^{l v}$ Sheldon Hackney, From Populism to Progressivism (Princeton, 1969), 33-34 lvi J. Morgan Kousser notes that the 1892 gubernatorial election demonstrated that 'ballot box fraud had become a vocation.' J. Morgan Kousser, The Shaping of Southern Politics: Suffrage Restriction and the Establishment of the One-Party South, 1880-1910 (New Haven, 1975), p. 43; Oates systemically countered the charges of electoral fraud at the 1894 election (the election in which he won). William C. Oates to John T. Morgan and James L. Pugh, March 12, 1896, John Tyler Morgan Papers, Correspondence, Box 6, Manuscript Division, Library of Congress, Washington, D.C. lvii Robert David Ward and William Warren Rogers, Labor Revolt in Alabama: The Great Strike of 1894 (Tuscaloosa, AL, 1965), 125.

lviii J.B. Blevins to William Coppinger, August 7, 1890, cited in Edwin S. Redkey, Black Exodus: Black Nationalist and Back-to-Africa Movements, 1890-1910 (New Haven, 1969), 8; Robert Saunders, "Populists and the Negro, 1893-1895," Journal of Negro History 54 (January 1960): 240-69 (quotation on 256); Hackney, 34-35. lix Oates to Morgan and Pugh, March 12, 1896, Morgan Papers.

lx Ibid.

${ }^{\text {lxi }}$ Lynchburg Daily Advance, October 10, 1893, quoted in Charles E. Wynes, Race Relations in Virginia, 1870-1902 (1961; rpt. Totowa, NJ, 1971), 49.

lxii Wynes, 49.

lxiii People's Party Paper, January 20, 1893, quoted in Joseph Gerteis, Class and the Color Line: Interracial Class Coalitions in the Knights of Labor and the Populist Movement (Durham, NC, 2007), 149.

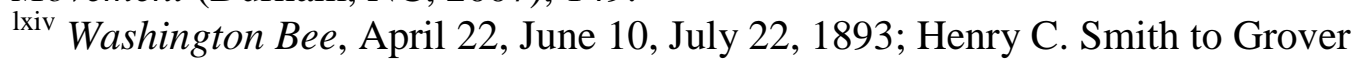
Cleveland, December 15, 1893, in Series 2, reel 81, Cleveland Papers, Manuscript Division, Library of Congress.

${ }^{\mathrm{lxv}}$ Colored American, December 10, 1898.

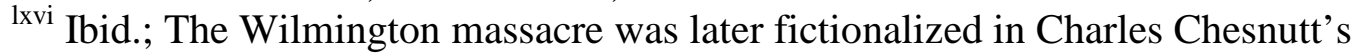
novel, The Marrow of Tradition, published some three years after the event. Charles W. Chesnutt, The Marrow of Tradition (1901; London, 1994); For more on the 1898 election, see Glenda Gilmore, Gender and Jim Crow: Women and the Politics of White Supremacy in North Carolina, 1896-1920 (Chapel Hill, 1996). 